\title{
Mobile health technology for gestational care: evaluation of the GestAção's app
}

\author{
Uso de tecnologia móvel para o cuidado gestacional: avaliação do aplicativo GestAção \\ Uso de tecnología móvil para el cuidado gestacional: evaluación de la aplicación GestAção
}

\section{Raimunda Magalhães da Silva' \\ ORCID: 0000-0001-5353-7520 \\ Christina César Praça Brasil' \\ ORCID: 0000-0002-7741-5349 \\ Indara Cavalcante Bezerra' ORCID: 0000-0003-0647-2490}

Francisca Francisete de Sousa Nunes Queiroz ORCID: 0000-0002-2933-4974

'Universidade de Fortaleza. Fortaleza, Ceará, Brazil.

How to cite this article:

Silva RM, Brasil CCP, Bezerra IC, Queiroz FFSN. Mobile health technology for gestational care: evaluation of the GestAção's App. Rev Bras Enferm. 2019;72(Suppl 3):266-73. doi: http://dx.doi.org/10.1590/0034-7167-2018-064

Corresponding Author: Indara Cavalcante Bezerra E-mail: indaracavalcante@yahoo.com.br

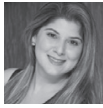

Submission: 06-13-2018 Approval: 04-26-2019

\begin{abstract}
Objective: to evaluate the GestAção application, based on the experience of pregnant women use. Method: an evaluative, applied, methodological, quantitative-qualitative study. This tool was evaluated by 13 pregnant women through questionnaires for sociodemographic profile characterization and Likert scale use to calculate Content Validity Index (CVI); and semi-structured interview, with analysis based on Semiotics. Results: the study evidenced a significant level of satisfaction of pregnant women with the application use, considering the objectives $(C V I=0.92)$, structure and presentation $(C V I=0.86)$, and relevance $(C V I=0.92)$. Final considerations: the GestAção application obtained an overall CVI of 0.90 , evidencing it as a facilitating and supporting technology in the empowerment of pregnant women interested in obtaining knowledge about pregnancy. It has been proved to be a powerful tool to qualify good practices in nursing consultation.

Descriptors: Telemedicine; Mobile Health Units; Health Technology Assessments; Portable Electronic Apps; Primary Care Nursing
\end{abstract}

\section{RESUMO}

Objetivo: avaliar o aplicativo GestAção, com base na experiência de uso das gestantes. Método: estudo de natureza avaliativa, aplicada, metodológica, com abordagem quanti-qualitativa. A ferramenta tecnológica foi avaliada por 13 gestantes por meio de questionários para a caracterização do perfil sociodemográfico e o uso da escala de Likert, para calcular o Índice de Validade de Conteúdo (IVC) do aplicativo; e entrevista semiestruturada, com análise fundamentada na Semiótica. Resultados: o estudo evidenciou significativo nível de satisfação das gestantes com o uso do aplicativo, considerando os objetivos (IVC=0,92), estrutura e apresentação (IVC=0,86), e relevância (IVC=0,92). Considerações finais: o aplicativo GestAção obteve IVC geral de 0,90, evidenciando-o como tecnologia facilitadora e coadjuvante no empoderamento das gestantes interessadas em obter conhecimentos sobre o período gravídico, mostrando-se uma potente ferramenta para qualificar as boas práticas na consulta de enfermagem.

Descritores: Tecnologia em Saúde; Aplicativos Móveis; Promoção da saúde; Cuidados de Enfermagem; Gestação.

\section{RESUMEN}

Objetivo: evaluar la aplicación GestAção basada en la experiencia de uso de las gestantes. Método: estudio de naturaleza evaluativa, aplicada, metodológica, con abordaje cuantitativo. La herramienta tecnológica fue evaluada por 13 gestantes por medio de cuestionarios para la caracterización del perfil sociodemográfico y el uso de la escala de Likert, para calcular el Índice de Validez de Contenido (IVC) de la aplicación; y entrevista semiestructurada, con análisis fundamentado en la Semiótica. Resultados: el estudio evidenció un significativo nivel de satisfacción de las gestantes con el uso de la aplicación, considerando los objetivos (IVC $=0,92)$, estructura y presentación (IVC $=0,86$ ), y relevancia (IVC $=0,92)$. Consideraciones finales: la aplicación GestAção obtuvo IVC general de 0,90, evidenciándolo como tecnología facilitadora y coadyuvante en el empoderamiento de las gestantes interesadas en obtener conocimientos sobre el período gravídico. Se mostró una potente herramienta para calificar las buenas prácticas en la consulta de enfermería.

Descriptores: Tecnología Biomédica; Aplicaciones Móviles; Promoción de la Salud; Atención de Enfermería; Embarazo. 


\section{INTRODUCTION}

Health technologies evolution and widespread acquisition of cell phones and smartphones, allow improvement of the health conditions of different population groups in different age groups. Many people use the smartphone as the primary means to access information, as well as a useful tool for health management ${ }^{(1)}$.

Thus, the use of technology offered by mobile devices (telephony, texts, videos, internet and applications for smartphones) is a reality that has transformed people's daily lives through differentiated learning and entertainment experiences. It also brings benefits to health care and greater possibility of knowledge apprehension by users, professionals and researchers, especially when these resources are associated with therapeutic measures ${ }^{(2-3)}$.

There is a wide range of possibilities offered by these technologies in favor of health promotion in the most diverse contexts, including pregnancy. In this sense, there are numerous examples of interventions being used to support women during pregnancy and childbirth, as well as in neonatal and child health. There is evidence of women seeking information about the current pregnancy or when they have plans to become pregnant, which are driven by inexperience or the desire to share their experiences with others. In this process, they also seek, through consultation with the health professional, to reaffirm the information that was obtained from these technological tools $s^{(4)}$.

Research reports the benefits of using applications in health interventions with regard to improving clinical decision-making, patient education, and qualification of health professionals. Most available health applications are considered strategies for health promotion, well-being, and disease prevention ${ }^{(4-5)}$.

Among information and communication technologies, the area of mHealth (mobile health) as an eHealth component, which includes health practices supported by mobile devices, such as mobile phones, patient monitoring devices, other wireless tools. MHealth resources are characterized by the safe and accessible use of information technologies for health care, including care, surveillance, health education, teaching, and research ${ }^{(6)}$.

The GestAção was conceived and developed by an interdisciplinary team from the Universidade de Fortaleza (UNIFOR) in 2014. It is a technological tool aimed at the empowerment of pregnant women about gestational health care. It contains multimedia information about pregnancy phases associated with easy-tounderstand contents, as well as resources for monitoring and monitoring maternal health, and fetal evolution.

Before the last statistic of the Sistema de Informação da Atenção Básica (Primary Care Information System), the number of pregnant women in Brazil in 2015 was 5,660,211 $1^{(7)}$. In this context, this quantitative is one of the reasons that justify the importance of universal tools use. For example, mobile applications with information necessary for self-care and empowerment of the pregnant woman to appropriate knowledge about the development of pregnancy, risk prevention and health promotion. In order for these resources to be used safely and effectively by the users, it is necessary that their information, handling, appearance, functionalities, among other characteristics, be evaluated and validated ${ }^{(8)}$.

In view of the above, is fundamental evaluating the GestAção application's quality regarding the provision of safe gestational health care, through experiences of pregnant women ${ }^{(9)}$. The experience of patients and users of technologies, and the general public, through applications use, can contribute to a more rigorous evaluation, collaborating for a better analysis and use of health technologies ${ }^{(8)}$.

\section{OBJECTIVE}

To evaluate the GestAção application, based on the experience of pregnant women use followed-up in prenatal consultations in public health services in a capital city of Northeast Brazil.

\section{METHOD}

\section{Ethical aspects}

The ethical-legal procedures of the research followed the norms contained in Resolution 466 of December 12, 2012, of the Brazilian Health Board (Conselho Nacional de Saúde), which indicates the directives and norms of research involving human beings. The study is an unfolding of the "mHealth para promoção de saúde da mulher: inovação tecnológica para melhoria da qualidade da assistência pré-natal" project funded by the Fundação Cearense de Apoio ao Desenvolvimento Científico e Tecnológico (FUNCAP - Scientific and Technological Development Foundation of (eará State) and approved by the Ethics Committee of the Universidade de Fortaleza.

\section{Theoretical-methodological framework}

This is an evaluative research, with quantitative-qualitative approach, which takes into account the experience of using the tool under study by pregnant women. Semiotics ${ }^{(10)}$ was adopted as a theoretical-methodological framework, as a science of systems and sign processes in culture and nature. Semiotics studies forms, types, signs systems, and effects of signs use in life, observing signs, clues, symptoms or symbols. The processes in which signs develop their potential give rise to signification, communication, and interpretation ${ }^{(10)}$.

Therefore, this methodology served the qualitative aspects of the research. It favored knowledge of apprehension forms and elements significance contained in the study application, besides the experience of using pregnant women, which allowed the expression of their attitudes and learning.

\section{Design, place of study}

This is an applied and methodological study, carried out in the city of Fortaleza, Ceará, Brazil, from June to December 2017. It was carried out in two Primary Health Care Units (UAPS - Unidades de Atenção Primária à Saúde), in the Pregnant Women Care Program developed at Universidade de Fortaleza and in a state maternity hospital.

The GestAção was developed in 2014, in an earlier study carried out by an interdisciplinary team from the Universidade de Fortaleza. At that time, the doubts of several pregnant women about the gestational period were investigated from a broad review of the Brazilian and international literature, which based the tool construction. In this phase, after its conception and development, the application was presented to 18 pregnant women. They expressed opinions about usability ${ }^{(11)}$, written and visual language, information understanding, design, and suitability of use time. 
It should be emphasized that this article refers to the validation phase of the application with pregnant women, in which the daily use experience is the focus of the evaluation performed.

\section{Data source}

For the collection, women who were undergoing prenatal care in the first or second gestational trimester; who were approached in the waiting room on days of prenatal visits; who had smartphones with Android technology; who had access to the Internet in their daily lives (via Wi-Fi, 3G, 4G); and availability to participate in the meetings for presentation and training for the use of technology, were included. Women who were at risk for pregnancy were excluded from the study, as well as some other motives related to their mobile devices such as: reduced data packet, slow connection speed, limited Wi-Fi access, and loss of contact by phone number change.

At the end, the research had the participation of 13 pregnant women. It should be emphasized that the qualitative approach dispenses with the'sampling technique' and focuses on the profile of the sample of participants, since the method seeks rigor of the validity of the data collected, since the observation of the subjects and their listening must be accurate. This tends to bring the researcher very close to the essence of the question under study ${ }^{(12)}$.

Coluci, Alexandre and Milani's ${ }^{(13)}$ precepts establish recommendations of the number of participants in technology validation processes, showing that the literature on the number and qualification of judges in the validation processes presents a great variety. For the present study, we considered Lynn's ${ }^{(14)}$ recommendations that admit a minimum of five and a maximum of ten evaluators; and t Haynes, Richard and Kubany's ${ }^{(15)}$ guidelines that advocate the participation of six to twenty subjects. These precepts are aligned with design, redesign, and evaluation proposals as indicated by Rogers, Sharp and Preece ${ }^{(11)}$. In this sense, the sample obtained in this study is valid and adequate for the achievement of the proposed objectives.

\section{Collection and organization of data}

Data collection occurred between June and October 2017. Initially, the questionnaire was applied to the characterization of pregnant women, to verify their health conditions and if they had mobile phones that supported the use of the application in question. After this stage, an individual training, lasting approximately 30 minutes, was conducted by the research team. Furthermore, the tutorial of the application was presented, containing explanations about its use. The GestAção application was then installed on their mobile phones and made available for handling for a period ranging from one to three months.

During the study period, the pregnant women maintained contact with the researchers, being able to call them at any moment by telephone for the clarification of doubts. The application had a monitoring center of the users that allowed an effective monitoring as to the frequency of access and time of navigation in the tool.

At the end of the period proposed for the use of the application (from one to three months of use), individual meetings were held. They were performed at the prenatal follow-up site and/or at the participants' homes, from November to December 2017. At that time, a questionnaire structured on the Likert scale was applied to the participants. This questionnaire included three chunks of questions to evaluate the use of the tool: objectives (08 questions), structure and presentation (13 questions), and relevance (10 questions) ${ }^{(16)}$.

In order to complement and deepen the knowledge about the experience of pregnant women regarding the GestAção use, interviews were conducted with open questions about the application for the pregnant woman to express opinions, feelings and learning.

\section{Data analysis}

Sociodemographic data were organized and described according to the absolute and relative frequencies. The results analyzed, based on the Likert scale, indicated the Content Validation Index (CVI) of the application ${ }^{(16)}$.

The interviews were recorded and transcribed reliably, preserving the richness of detail. To protect the identity of participants, they were designated by the letter $\mathrm{P}$ (pregnant), followed by numbers.

Women's reports were organized according to the Content Analysis (pre-analysis, material exploration and treatment of results) ${ }^{(17-18)}$. They were presented according to the themes evaluated in the three application chunks (objective, structure and relevance). The interpretation was based on the theoretical concepts of Semiotics ${ }^{(10)}$. This path helped in understanding how pregnant women appropriate and signify their interaction with technology. This made it possible to know and understand the ideas, representations and motivations related to the GestAção application use.

\section{RESULTS}

\section{Sociodemographic profile and health conditions of preg- nant women}

The ages of pregnant women ranged from 13 to 35 years, with an average of 22 years, of which $47.06 \%$ were younger than 18 years. Among the participants, $35.29 \%$ were married or living in a stable union with a partner, while $64.71 \%$ participants were single. As for schooling, $23.51 \%$ had incomplete elementary and middle school, $29.41 \%$ incomplete high school, and $29.41 \%$ complete high school. The monthly family income of the majority (52.94\%) was up to a minimum wage. With regard to professional life, $70.59 \%$ did not have work.

Regarding health conditions, 11 were primigravidae. The majority $(88.24 \%)$ reported no chronic diseases and $17.65 \%$ reported having a urinary infection when they completed the questionnaire.

When the pregnant women were questioned about the doubts about their current pregnancy, 52.94\% answered that they had no doubts. As for the use of digital technologies, all participants used applications on their cell phones as well as surfing the social networks. It is noteworthy that $47.18 \%$ of pregnant women did not know of any pregnancy application.

\section{Application evaluation by pregnant women}

For this study, it was considered, based on the Likert scale, that the items evaluated with Content Validation Index (CVI) below 0.79 would be revised and adjusted. The items evaluated with CVI 0.79 or $>$ would be considered satisfactory ${ }^{(16)}$. 
Chart 1 expresses the evaluation of the pregnant women in relation to the first chunk of questions regarding the objectives of the application, which presented mean CVI of 0.92. In seven of the eight items, there is a high level of participants' satisfaction with the Management (CVI values between 0.92 and 1).

Chart 1 - Content Validation Index of the analysis of the objectives of the application, Fortaleza, Ceará, Brazil, November to December 2017

\begin{tabular}{|l|c|}
\hline \multicolumn{1}{|c|}{ Objectives } & CVI \\
\hline 1. Is the language used in the application easy to understand? & 1 \\
\hline $\begin{array}{l}\text { 2. Are the information contained in the application clear and } \\
\text { clarify your questions about pregnancy? }\end{array}$ & 0.92 \\
\hline $\begin{array}{l}\text { 3. Did the application content provide tips on taking care of } \\
\text { your health during pregnancy? }\end{array}$ & 1 \\
\hline $\begin{array}{l}\text { 4. Has the application helped to change your behavior } \\
\text { regarding pregnancy care? }\end{array}$ & 0.69 \\
\hline $\begin{array}{l}\text { 5. Did the application help you understand the baby's } \\
\text { development? }\end{array}$ & 1 \\
\hline $\begin{array}{l}\text { 6. Is the application content motivating and encourages you } \\
\text { to continue browsing? }\end{array}$ & 0.92 \\
\hline \begin{tabular}{l} 
7. Are you satisfied with the use of the application? \\
\hline $\begin{array}{l}\text { 8. Can the application help other women get information } \\
\text { about pregnancy? }\end{array}$
\end{tabular} & 0.92 \\
\hline CVI mean & 0.92 \\
\hline
\end{tabular}

Note: CVI - Content Validation Index.

Only item 4 was evaluated as unsatisfactory $(C V I=0.69)$. It is about the opinion of pregnant women about the possibility of the application to promote changes in behavior in relation to pregnancy care, which can be verified from the following reports:

With the use of the application, not much has changed [...], but we start reading and also see the importance of food that helps a lot. Although I have not changed behavior, there is a lot of information l learned. (P1)

Changing, changing [...] I did not change, but I saw many things there [in the application] that were things I did not know and found interesting. (P8)

The low CVI in item 4 may be related to the short period of time and to the low frequency of use of the application by the participants. The researchers found that the tool was not accessed with the frequency required by some pregnant women, which required them to encourage participants to a more routine use. To do this, they sent text messages or phoned the participants who were in this situation.

On the other hand, most respondents pointed out that the application presents important information regarding the position of sleeping, feeding, sex in pregnancy, and practice of physical activity. This may lead to behavioral changes, even if it is not readily perceived by pregnant women. According to them, the knowledge gained from GestAção helped them to act differently. This shows the potential of the tool in causing women to modify their way of acting in relation to some aspects during the gestational period.
I am learning many things in it. I know how to sleep, how l'm going to eat, many things [...].The application is teaching me many things about pregnancy. (P2)

Well, in fact, it reinforced some more principles that I already had regarding both food and exercise and these things, I think it's important [...]. (P3)

I mostly changed my food habits. I was already doing physical activity [...], but now I decreased the intensity and frequency of the exercises I did, so as not to harm my baby. (P6)

For me, what it [the application] has done is bringing information about feeding care, vaccines, information that I do not dare to ask the doctor about, whether or not I can have sex during pregnancy. I, for example, am not doing it, but then, by the application, I knew better about it and had more access to information on that subject. (P7)

The structure and presentation of the application, referring to the second chunk of questions, shows that the mean CVI was calculated at 0.86 . This indicates a high level of satisfaction with the tool, with CVI values varying from 0.85 to 1 , as shown in Chart 2. This analysis denotes considerable suitability of these aspects for the wide availability of the tool in the application stores.

Chart 2 - Content Validation Index of the analysis of the structure and presentation of the GestAção application, Fortaleza, Ceará, Brazil, November to December of 2017

\begin{tabular}{|l|c|}
\hline \multicolumn{1}{|c|}{ Structure and presentation } & CVI \\
\hline 1. Was the information easy to understand as it was presented? & 0.92 \\
\hline $\begin{array}{l}\text { 2. Does the structure and presentation of the material } \\
\text { facilitate learning about pregnancy? }\end{array}$ & 0.85 \\
\hline 3. Did you like the sequence in which the content was presented? & 1 \\
\hline $\begin{array}{l}\text { 4. Is the presentation of content and messages attractive } \\
\text { and encourages the use of the application? }\end{array}$ & 0.85 \\
\hline 5. Is the language presented clearly and objectively? & 0.92 \\
\hline $\begin{array}{l}\text { 6. Is the amount and type of information contained in the } \\
\text { application adequate and sufficient? }\end{array}$ & 0.77 \\
\hline $\begin{array}{l}\text { 7. Do illustrations (images) help in understanding the } \\
\text { content of the application? }\end{array}$ & 1 \\
\hline $\begin{array}{l}\text { 8. Are the illustrations (images) clear and easy to understand, } \\
\text { ie have good quality? }\end{array}$ & 0.85 \\
\hline $\begin{array}{l}\text { 9. Is the number of illustrations adequate for the content of } \\
\text { the educational material? }\end{array}$ & 0.69 \\
\hline $\begin{array}{l}\text { 10. Are the icons (images representing each function) adequate } \\
\text { and help the pregnant woman to use the application? }\end{array}$ & 0.62 \\
\hline \begin{tabular}{l} 
11. Are the colors applied to the text relevant and easy to read? \\
\hline 12. Is the size of the letters of the texts appropriate?
\end{tabular} & 0.92 \\
\hline 13. Does the font used make reading easier? & 0.85 \\
\hline CVI mean & 0.92 \\
\hline
\end{tabular}

Note: CVI - Content Validation Index

Among the 13 items in Chart 2, three presented lower than expected CVI values, being: item 6, related to the adequacy of 
the quantity and type of information contained in the application $(\mathrm{CVI}=0.77)$; item 9, referring to the number of illustrations $(\mathrm{CVI}=0.69)$; and item 10 regarding the adequacy of the image expression of the icons, if they help the pregnant woman to use the application $(\mathrm{CVI}=0.62)$. Based on the opinions expressed by the pregnant women, it was observed the alignment of the perception they had about the structure and the presentation of the application in relation to what they had already pointed out in the first chunk of questions about the objectives of the tool.

In the comments and suggestions of some pregnant women, there are notes that express the need to improve the structure and the presentation of the application in relation to the images available, mainly regarding quantitative and adequacy (item 9 of chunk 2):

What I least liked in the application, I think it was the issue of the images, I think I missed a lot. You could have many more images to make it easier to understand the texts and the guidelines. (P4)

It was good to have pictures of how to do physical exercises. This would be good to explain better [...] So the person could read and see what to do to not perform the wrong way. (P8)

Other issues related to images also related in chunk 2, obtained very positive evaluations. Items 7 (the illustrations help in understanding the content of the application) and 8(the illustrations are clear and easy to understand, that is, they are of good quality) indicate the following reports:

The question of the images is much better to see [...] show the gestational week in which you are. You go see [...] and the application explains it right. It's very interesting! (P1)

It has the picture and has the text explaining how many weeks I am and more or less baby weight [...] / really liked the photos that were well presented [...],so the image is very good and the text is rich too. (P3)

Also, in chunk 2 , item 10 obtained CVI of 0.62 , showing the need for adjustment. This assessment is aligned with similar opinions below:

Regarding the icon at the time of registration, it was confusing because [the application] already opens in the year we are and has no information saying to click on the year to see the others. (P1)

The third and final chunk of questions refers to the relevance of the application, being presented in Chart 3.

The evaluation of this chunk obtained mean CVI of 0.92. It evidenced the participants' excellent perception about the importance of the GestAção application after its insertion in daily life and meaning that users attributed to its use during pregnancy. Thus, it was observed that the level of satisfaction with the tool was high, with CVI ranging from 0.92 to 1 in nine of the 10 items.

Only item 7 of chunk 3 was classified discreetly below the acceptable index $(\mathrm{CVI}=0.77)$. This data shows that the users received information in several ways, that is, the application was not the only source of information. Some of them seek other sources to clarify their doubts as: friends, relatives, health professionals, Internet, magazines and others. It is worth reflecting on the security and veracity of these sources of information, as can be seen in the following report:
Chart 3 - Content Validation Index of the relevance analysis of the GestAção application, Fortaleza, Ceará, Brazil, November to December 2017

\begin{tabular}{|l|c|}
\hline \multicolumn{1}{|c|}{ Relevance } & CVI \\
\hline $\begin{array}{l}\text { 1. Does the material address the subjects necessary for the } \\
\text { pregnant woman's understanding of the development of a } \\
\text { healthy pregnancy? }\end{array}$ & 1 \\
\hline $\begin{array}{l}\text { 2. Is the material adequate to help the pregnant woman } \\
\text { identify the changes of her body during pregnancy? }\end{array}$ & 1 \\
\hline $\begin{array}{l}\text { 3. Does the application promote the understanding of the } \\
\text { pregnant woman about the development of her baby? }\end{array}$ & 0.92 \\
\hline $\begin{array}{l}\text { 4. Does the material address the issues necessary for follow- } \\
\text { up and adherence in the taking of drugs, vaccines and } \\
\text { supplements during the gestational period? }\end{array}$ & 0.85 \\
\hline $\begin{array}{l}\text { 5. Does the material address the issues of healthy eating for } \\
\text { pregnant women? }\end{array}$ & 0.92 \\
\hline $\begin{array}{l}\text { 6. Is the material adequate to assist pregnant women in } \\
\text { pregnancy care? }\end{array}$ & 0.92 \\
\hline $\begin{array}{l}\text { 7. Has the application brought any information about the } \\
\text { pregnancy that you did not obtain otherwise? }\end{array}$ & 0.77 \\
\hline $\begin{array}{l}\text { 8. Do you know how to differentiate myths and truths about } \\
\text { pregnancy after using the application? }\end{array}$ & 0.92 \\
\hline 9. Did you enjoy using an app to learn about your pregnancy? & 1 \\
\hline $\begin{array}{l}\text { 10. Would you indicate the application so that other women } \\
\text { can get information about pregnancy? }\end{array}$ & 0.92 \\
\hline CVI mean & 0.92 \\
\hline
\end{tabular}

Note: CVI - Content Validation Index.

[...] Opinions are not lacking when you are pregnant, or when the child is born. Then you have to know how to filter. So the internet takes doubts there at the moment, because nowadays, the internet is full of things and you run to the internet, you kind of still get loose, right? (P1)

The overall CVI value of the application, considering the average CVI of the three analysis chunks, was 0.90 . This value is considered high in relation to the agreement of the pregnant women, attesting the validity of the tool $\mathrm{I}^{(10,13,19)}$.

\section{DISCUSSION}

The careful evaluation of the educational technologies developed for the Health field should be encouraged, which is why research is constantly carried out to evaluate the efficacy and reliability of these resources ${ }^{(20)}$. The importance of the evaluation approach demonstrates that this is a process capable of assessing the potential of a technological tool and the relevance of the attributes it brings. It presents itself as an indispensable step in the process of wide use of applications and other technologies ${ }^{(21)}$. Thus, it is emphasized that the evaluation of a technology must be carried out frequently and continuously due to the constant innovations and technological improvements required ${ }^{(22)}$.

It should be emphasized that it is recommended to know the application, verify the information presented and try to investigate them to verify its pertinence and theoretical basis ${ }^{(4)}$. In this sense, authors have already confirmed this idea and pointed out that 
health-driven applications, which are managed by professionals or researchers, are more effective in processes that seek to bring behavior changes to the population, since the trust generated by the information or activities presented, motivates users ${ }^{(21,23)}$.

Based on the experience of using the GestAção application, the evaluation of pregnant women indicated a high level of satisfaction. It has also shown that it is an important tool in information support, encouraging self-care during the gestational period and promoting health.

Regarding the objectives of the application, the pregnant women revealed the expansion of the knowledge after its use. The aspects that they considered important for the taking of healthy attitudes during the gestational process were highlighted, revealing the meanings that this knowledge and these behavioral changes brought to their daily life.

Health-related applications have great potential for good professional care practices in health promotion, encouraging users to become more aware and responsible in adopting healthy lifestyles ${ }^{(24)}$.

The interaction of the tool with the user can promote behavior change in favor of health ${ }^{(4)}$. In order to do so, a well-directed and clear language favors the understanding and the formulation or reformulation of meanings, which allows the adoption of behaviors that improve their health conditions.

Nursing consultation is well regarded by primary care users, due to the educational relationship it has, providing autonomy to the user, improving their quality of life and providing greater bonding with the nurse and the health unit team ${ }^{(25)}$. This moment is opportune so that the use of the application is encouraged and supervised by the nurse, which can potentiate the empowering action of the pregnant woman regarding self-care during pregnancy.

The nurse has occupied a central place in the health care of women, which transcended the pregnancy-puerperal cycle and expanded the actions in search of comprehensive care. This occurred since the creation of Programa de Humanização do Pré-Natal e Nascimento (PAISM - Women's Health Care Program) in 1984, in addition to other policies, such as Programa de Humanização does Pré-Natal e Nascimento (PHPN - Prenatal and Birth Humanization Program) and Política Nacional de Atenção Básica (PNAB - National Primary Care Policy).

Policies have reinforced the implementation of actions focused on minimum criteria for quality prenatal care. In this context, the nurse has legal support for comprehensive prenatal follow-up of low risk pregnant women. In the Primary Health Care Network (Rede de Atenção Primária à Saúde), it is expected that these professionals will be responsible for this kind of assistance. The regulation of the nursing exercise considers that the nurse must, as a member of the health team, perform nursing consultation. It should also provide quality care for the expectant, parturient, and puerperal women, in addition to carrying out health education activities ${ }^{(26)}$.

In fact, nursing consultation represents an important health education tool, since it favors a bond of trust, listening space and openness for the transmission of knowledge ${ }^{(26)}$. Therefore, prenatal care may be more qualified by the use of technologies, such as an application.

Returning to the object of this study, the evaluation of the 13 items of chunk 2 (Chart 2) related to the GestAção's structure and presentation, according to the pregnant women's speech, showed that the tool presents information that is easy to understand, adequate images, appropriate colors, among others features that expose good application quality. A similar research aimed at developing and evaluating an application for vocal health management, pointed out that the interaction of the user with hypertexts and images promotes speed in the learning process, besides promoting the acquisition of new knowledge $\mathrm{e}^{(27)}$. Other authors point out that in order to have positive effects on the usability of a tool, the structure and presentation must be precise, clear and easy to understand ${ }^{(4,22)}$.

The evaluation of GestAção brought to light some aspects that represented the perception of the pregnant women, showing the experiences and the good contributions that the application provided. However, some items were not well evaluated, indicating the need for in-app adjustments. Studies show that the process of evolution of technologies must be constantly improved ${ }^{(28-29)}$. Suggestive considerations of the evaluators for the tool in development are of fundamental importance to reduce possible usability barriers ${ }^{(21-22)}$. In this sense, the suggestions of the participants regarding the development of the application were evaluated by the researchers and those considered relevant were incorporated into GestAção.

Regarding relevance, confidence that the pregnant women attributed to the evaluated device stands out and how they valued this function. In summary, the credibility attributed to the information provided by the application is expressed positively by the participants in the interviews. This shows the important impact of the tool in the context of health promotion, risk prevention, and implementation of best care practices.

Literature points out that health education practices occupy a prominent position in the promotion of collective health, affirming that educating the population on the aspects that impact on their health conditions, promoting the co-responsibility of individuals and communities, provide healthy attitudes capable of improve the quality of life and reduce. Thus, educational practices in the context of health are considered as vehicles transforming practices and individual behaviors ${ }^{(30)}$.

It is a fact that behavioral changes are perceived effects in the medium and long term, since the incorporation of new knowledge goes against cultural assimilation, occurring in a complex and subjective way. Nonetheless, in this study, the short time of use of the application may be related to the opinion of the pregnant women regarding the change of behavior regarding pregnancy care was unsatisfactory.

From the perspective of Semiotics ${ }^{(10)}$, it is clear that the understanding established in relation to the application and the meaning attributed by the pregnant women to the GestAção. It is evidenced that, besides being a transmitter of knowledge, it also becomes a facilitator of the educational process, making users co-responsible for their attitudes and giving them good experiences of use and learning with technology.

\section{Study limitations}

The limitation of this study was the difficulty of capturing and maintaining contact with pregnant women, which explains the reduced number of participants. Application usage experience time ranged from one to three months. Frequency of use was not previously defined as an evaluative parameter, which may 
have interfered with the opinion of the pregnant women about the CVI index below the value considered satisfactory (0.79), related to the change in behavior resulting from the use of the application (item 4, chunk 1). In analysis, it was considered that this 'change in behavior' could demand more time and greater frequency of use in the research.

\section{Contributions to the Nursing field}

This article emphasizes the role of nurses in an interprofessional and innovative approach in the field of health technologies, promoting health education, with emphasis on the gestational period. It also facilitates interaction with users, making the prenatal visit more efficient and qualified.

\section{FINAL CONSIDERATIONS}

The role of nurses in the health care of women has been central and has been consolidating over the years, supported by best care practices and public health policies. Nursing consultation and prenatal care are among the essential actions developed in Primary Health Care.

MHealth technologies can boost nursing consultations and empower pregnant women with regard to self-care during pregnancy and puerperium. In this study, the experience evaluation of use of the GestAção application by pregnant women obtained am overall CVI of 0.90 , demonstrating a high index of satisfaction of this technology of support to the pregnancy. Participants' speeches considered the tool to facilitate and support the construction and improvement of knowledge for pregnant women interested in qualifying self-care during pregnancy.

The application evaluation regarding the objective, structure and relevance, measured the level of user satisfaction with the tool from a multifocal view, capturing different aspects. Regarding the objectives of the application, users understood the content addressed. Regarding the structure, most of the items were evaluated positively, evidencing that the technology is interactive, attractive and easy to handle. With regard to relevance, the pregnant women reported that the application can directly impact the process of empowerment during pregnancy.

These considerations show that GestAção is a powerful tool in contributing to prenatal care, especially when conducted and encouraged by nurses. It can also be indicated by the multidisciplinary health team to its patients. It can also compose an interactive work methodology in public and private health services, since this tool offers reliable and important information to pregnant women, helping to record information and follow up these women.

\section{REFERENCES}

1. Kennelly MA, Ainscough K, Lindsay K, O'Sullivan E, Gibney ER, McCarthy M, et al. Pregnancy, exercise and nutrition with smartphone application support: a randomized controlled trial. Obstet Gynecol. 2018;131(5):818-26. doi: 10.1097/AOG.0000000000002582

2. Lee Y, Moon M. Utilization and content evaluation of mobile applications for pregnancy, birth, and child care. Healthc Inform Res. 2016;22(2):73-80. doi: 10.4258/hir.2016.22.2.73

3. Oliveira RM, Duarte AF, Alves D, Furegato ARF. Development of the TabacoQuest app for computerization of data collection on smoking in psychiatric nursing. Rev Latino-Am Enfermagem. 2016;24:e2726. doi: 10.1590/1518-8345.0661.2726

4. Lee SH, Nurmatov UB, Nwaru BI, Mukherjee, M, Grant L, Pagliari C. Effectiveness of mHealth interventions for maternal, newborn and child health in low- and middle-income countries: Systematic review and meta-analysis. J Glob Health. 2016;6(1):010401. doi: 10.7189/jogh.06.010401

5. Peng W, Kanthawala S, Yuan S, Hussain SA. A qualitative study of user perceptions of mobile health apps. BMC Public Health. 2016;16(1):1158. doi: 10.1186/s12889-016-3808-0

6. World Health Organization (WHO). mHealth: new horizons for health through mobile technologies: second global survey on eHealth [Internet]. Geneva:WHO; 2011 [cited 2017 Dec 20]. Available from: https://apps.who.int/iris/handle/10665/44607

7. Ministério da Saúde (BR). Sistema de Informação de Atenção Básica (SIAB). DATASUS. Tecnologia da Informação a Serviço do SUS. Brasil no Gestantes segundo ano e período. [Internet] Brasília: Ministério da Saúde; 2015 [cited 2017 May 30]. Available from: http://tabnet.datasus. gov.br/cgi/tabcgi.exe?siab/cnv/SIABSBR.DEF

8. Rocha TAH, Fachini LA, Thumé E, Silva NC, Barbosa ACQ, Carmo M, et al. Saúde Móvel: novas perspectivas para a oferta de serviços em saúde. Epidemiol Serv Saúde. 2016;25(1):159-70. doi: 10.5123/s1679-49742016000100016

9. Castro R, Elias FTS. Envolvimento dos usuários de sistemas de saúde na Avaliação de Tecnologias em Saúde (ATS): uma revisão narrativa de estratégias internacionais. Interface (Botucatu). 2018;22(64):97-108. doi: 10.1590/1807-57622016.0549

10. Santaella L, Noth W. Introdução a semiótica: Passo a passo para compreender os signos e a significação. São Paulo: Paulus, 2017.

11. Rogers Y, Sharp H, Preece J. Design de Interação: Além da Interação Homem-Computador. $3^{a}$ ed. Porto Alegre: Bookman; 2013.

12. Turato ER. Qualitative and quantitative methods in health: definitions, diferences and research subjects. Rev Saúde Pública. 2005;39(3):50714. doi: 10.1590/S0034-89102005000300025

13. Coluci MZO, Alexandre NMC, Milani D. Construção de instrumentos de medida na área da saúde. Ciênc Saúde Colet. 2015;20(3):925-36. doi: 10.1590/1413-81232015203.04332013

14. Lynn MR. Determination and quantification of content validity. Nurs Res. 1986;35(6):382-5. 
15. Haynes SN, Richard DCS, Kubany ES. Content validity in psychological assessment: a functional approach to concepts and methods. Psychol Assess.1995;7(3):238-47.

16. Sampieri RH, Collado CF, Lucio MPB. Metodologia de pesquisa. 5a ed. Porto Alegre: Penso; 2013.

17. Bardin L. Analise de conteúdo. Lisboa: Edições 70; 2011.

18. Minayo MCS. O desafio do conhecimento: pesquisa qualitativa em saúde. 14ª ed. São Paulo: Hucitec; 2014.

19. Souza AC, Alexandre NMC, Guirardello EB. Psychometric properties in instruments evaluation of reliability and validity. Epidemiol Serv Saúde. 2017;26(3):649-59. doi: 10.5123/s1679-49742017000300022.

20. Heffernan KJ, Chang S, Maclean ST, Callegari ET, Garland SM, Reavley NJ, et al. Guidelines and recommendations for developing interactive eHealth apps for complex messaging in health promotion. JMIR Mhealth Uhealth. 2016;4(1):e14. doi: 10.2196/mhealth.4423

21. Salvador PTCO, Mariz CMS, Vítor AF, Ferreira Jr MA, Fernandes MID, Martins JCA, et al. Validation of virtual learning object to support the teaching of nursing care systematization. Rev Bras Enferm [Internet]. 2018;71(1):11-9. doi: 10.1590/0034-7167-2016-0537

22. Kayyali R, Peletidi A, Ismail M, Hashim Z, Bandeira P, Bonnah J. Awareness and use of mHealth apps: a study from England. Pharmacy (Basel). 2017;5(2).pii:E33. doi: 10.3390/pharmacy5020033

23. Martin CK, Gilmore LA, Apolzan JW, Myers CA, Thomas DM, Redman LM Smartloss: A Personalized Mobile Health Intervention for Weight Management and Health Promotion JMIR Mhealth Uhealth. 2016;4(1):e18. doi: 10.2196/mhealth.5027

24. Delgado M, Miranda S, Rodrigues PF. Uma avaliação das aplicações mobile classificadas em saúde e fitness. Acta Port Nutr. 2017;(8):22-6. doi: 10.21011/apn.2017.0805

25. Maranha NB, Silva MCA, Brito IC. A consulta de enfermagem no cenário da atenção básica e a percepção dos usuários: revisão integrativa. Academus Rev Cient Saúde [Internet]. 2017 [cited 2018 May 19];2(1). Available from: https://smsrio.org/revista/index.php/reva/article/view/246

26. Silva CS, Souza KV, Alves VH, Cabrita BAC, Silva LR. Atuação do enfermeiro na consulta de pré-natal: limites e potencialidades. J Res Fundam Care Online. 2016;8(2):4087-98. doi: 10.9789/2175-5361.2016.v8i2.4087-4098

27. Carlos DAO, Magalhães TO, Vasconcelos Filho JE, Silva RM, Brasil CCP. Concepção e avaliação de tecnologia mHealth para promoção da saúde vocal. RISTI. 2016;(19):46-60. doi: 10.17013/risti.19.46-60

28. Lavaissiéri P, Melo PED. Prototype app for voice therapy: a peer review. CoDAS. 2017;29(1):e20150300. doi: 10.1590/2317-1782/20172015300

29. Heffernan KJ, Chang S, Maclean ST, Callegari ET, Garland SM, Reavley NJ, et al. Guidelines and recommendations for developing interactive eHealth apps for complex messaging in health promotion. JMIR Mhealth Uhealth. 2016;4(1):e14. doi: 10.2196/mhealth.4423

30. Janini JP, Bessler D, Vargas AB. Educação em saúde e promoção da saúde: impacto na qualidade de vida do idoso. Saúde Debate. 2015;39(105):480-90. doi: 10.1590/0103-110420151050002015 